\title{
ANALISIS KARAKTERISTIK PERUSAHAAN, INTENSITAS ASET TETAP DAN KONSERVATISME AKUNTANSI TERHADAP TAX AVOIDANCE
}

\author{
AVITA NIA NINGSIH \\ Prodi Akuntansi S1, Universitas Pamulang \\ ira@unpam.ac.id \\ WIWIT IRAWATI \\ Prodi Akuntansi S1, Universitas Pamulang \\ wiwitira@unpam.ac.id \\ HARRY BARLI \\ Prodi Akuntansi S1, Universitas Pamulang \\ dosen01058@unpam.ac.id \\ ANGGA HIDAYAT \\ Prodi Akuntansi S1, Universitas Pamulang \\ dosen01189@unpam.ac.id
}

\begin{abstract}
This study aims to obtain empirical evidence about the influence of Company Characteristics, Intensity of Fixed Assets and Accounting Conservatism on Tax Avoidance. The independent variables used are Company Characteristics, Intensity of Fixed Assets and Accounting Conservatism. The dependent variable used is Tax Avoidance. The population in this study is mining companies listed on the Indonesia Stock Exchange in the 2014-2018 period. Samples collected by purposive sampling method. The number of companies sampled in this study were 13 companies. The method of analysis of this study uses multiple linear regression. The results of research conducted indicate that the variable Company Characteristics influence on Tax Avoidance, Fixed Asset Intensity has no effect on Tax Avoidance and Accounting Conservatism has no effect on Tax Avoidance. Simultaneously all free variables (Characteristics of Company, Fixed Asset Intensity and Accounting Conservatism) affect the Tax Avoidance.
\end{abstract}

Keywords: Company Characteristics; Fixed Assets Intensity; Conservatism Accounting; Tax Avoidance. 


\section{PENDAHULUAN}

Beban pajak adalah unsur yang senantiasa diperhatikan dan dijaga oleh entitas yang pada umumnya menghendaki sekecil mungkin, oleh karena itu entitas sangat berkepentingan akan manajemen pajak atau yang sering di sebut Tax Planning agar pajak yang dibayarkan memberi kontribusi maksimal bagi entitas, (Pohan, 2013: 13). Dari sudut pandang perusahaan pajak merupakan biaya yang akan mengurangi laba sedangkan salah satu tujuan perusahaan adalah memaksimalkan kesejahteraan pemegang saham atau investor dengan cara memaksimalkan nilai perusahaan guna memperoleh laba maksimum. Oleh karena itu, entitas melakukan berbagai cara untuk menghindari dan mengurangi jumlah pembayaran pajaknya. (Irawati \& Sari, 2019).

Manajemen pajak merupakan bagian integral dari perencanaan strategi perusahaan. Tax Panning dilakukan dengan mencari berbagai celah yang dapat ditempuh dalam koridor peraturan perpajakan (loopholes) agar perusahaan dapat membayar pajak dalam jumlah minimal tetapi tidak melanggar hukum. Tax Planning seperti ini sering juga dikenal sebagai penghindaran pajak (tax avoidance). Yakni usaha untuk meminimalisasi kewajiban pajak perusahaan dengan cara yang legal. Penghindaran pajak merupakan persoalan yang rumit, karena di satu sisi menurut peraturan pajak tidak dilarang akan tetapi di sisi lain sering kali mendapat sorotan yang kurang baik karena dianggap memiliki konotasi negatif di mana praktek penghindaran pajak berdampak pada tergerusnya basis pajak yang merugikan negara dan mengakibatkan berkurangnya penerimaan pajak yang dibutuhkan oleh negara. Sebagaimana sudah diketahui masyarakat umum bahwa pajak adalah tulang punggung sumber pembiayaan nasional dalam rangka mensukseskan program-program pembangunan nasional yang akan meningkatkan pertumbuhan ekonomi serta kesejahteraan bangsa dan masyarakat pada umunya.

Konservatisme merupakan alasan sebagai tendensi yang dimiliki oleh seorang akuntan maupun manajer yang mensyaratkan tingkat tinjauan yang lebih detail dan lebih cermat untuk mengakui laba (good news in earnings) dibandingkan mengakui rugi (bas news in earning). Konservatisme terkait dengan melaporkan pandangan yang paling tidak optimis saat menghadapi ketidakpastian dalam pengukuran, (Jaya dkk, 2013). Hal yang sering terjadi sehubungan dengan konsep ini adalah keuntungan tidak diakui sampai benar-benar terjadi. Konservatisme akuntansi dalam perusahaan diterapkan dalam tingkat yang berbeda-beda. Salah satu faktor yang sangat menentukan tingkat konservatisme dalam pelaporan keuangan suatu perusahaan adalah komitmen manajemen dan pihak internal perusahaan dalam memberikan informasi yang transparan, akurat dan tidak menyesatkan bagi investornya (Baharudin dan Wijayanti, 2011 ).

Hal inilah yang menyebabkan prinsip konservatisme yang diterapkan perusahaan dikatakan secara tidak langsung dapat mempengaruhi ketepatan hasil laporan keuangan, dimana laporan keuangan tersebut dijadikan dasar pengambilan keputusan bagi manajemen dalam mengambil kebijakan terkait dengan perusahaan. Hal ini tentunya termasuk juga dalam hal perpajakan, khususnya 
terkait dengan penghindaran pajak. Penelitian terkait konservatisme akunatnsi telah banyak dilakukan, salah satunya penelitian yang dilakukan Bataro Wiryo Pramudito dan Maria M. Ratana Sari (2015) yang menemukan bahwa konservatisme akuntansi tidak berpengaruh terhadap penghindaran pajak.

Intensitas Aset Tetap merupakan rasio yang menandakan intensitas kepemilikan aset tetap suatu perusahaan dibandingkan dengan total aset. Intensitas Aset Tetap terkait penghindaran pajak adalah dalam hal depresiasi (Dharma dan Agus, 2015). Kepemilikan aset tetap yang tinggi menghasilkan beban depresiasi atas aset tetap yang besar pula. Beban depresiasi yang bersifat deductible expense akan menambah total beban yang kemudian mengurangi laba bruto perusahaan sehingga laba kena pajak akan lebih kecil dengan adanya beban depresiasi yang melekat pada aset tetap tersebut dan menyebabkan pajak terutang akan lebih sedikit (Mulyani, 2014). Hasil penelitian yang dilakukan Ida Bagus Putu Fajar Adisamartha dan Naniek Noviari (2015) diperoleh Intensitas Aset Tetap tidak berpengaruh signifikan terhadap penghindaran pajak.Namun penelitian yang dilakukan oleh Putu Agus Ardiana (2016) menyatakan bahwa Intensitas Aset Tetap berpengaruh negative terhadap tax avoidance.

Leverage adalah intensitas penggunaan utang sebagai sumber dana perusahaan. Perusahaan yang menggunakan hutang akan memiliki beban bunga yang harus dibayar. Beban bunga tersebut akan mengurangi laba sehingga beban pajak dalam periode berjalan akan berkurang. Karakteristik Perusahaan yang diproksikan dengan Leverage sudah banyak diteliti antara lain oleh Ida Ayu Rosa Dewinta dan Putu Ery Setiawan (2016) yang menemukan bahwa leverage tidak berpengaruh terhadap tax advoidance, sedangkan penelitian Ardiana (2016) menunjukan bahwa leverage berpengaruh negatif terhadap tax avoidance. Hal ini menunjukan semakin tinggi leverage tetap akan menyebabkan menurunnya tingkat tax avoidance.

Perumusan masalah penelitian adalah : (1) Apakah Karakteristik Perusahaan berpengaruh terhadap Penghindaran Pajak? (2) Apakah Intensitas Aset Tetap berpengaruh terhadap Penghindaran Pajak? ; (3) Apakah Konservatisme Akuntansi berpengaruh terhadap Pernghindaran Pajak? ; (4) Apakah Karakteristik Perusahaan, Intensitas Aset Tetap dan Konservatisme Akuntansi bersama-sama berpengaruh terhadap Penghindaraan Pajak?

\section{TINJAUAN TEORI DAN PENGEMBANGAN HIPOTESIS}

\section{Teori Agensi}

Teori Agensi menyatakan hubungan kontrak antara agent (manajemen suatu usaha) dan principal (pemilik usaha). Hubungan keagenan tersebut terkadang menimbulkan masalah antara manajerdan pemegang saham atau biasanya disebut konflik kepentingan (agency conflict), konflik yang timbul sebagai akibat dari keinginan manajemen (agent) untuk melakukan tindakan yang sesuai dengan kepentingannya yang dapat mengorbankan kepentingan pemegang saham 
(principal) guna memperoleh return dan nilai perusahaan di masa mendatang. Keputusan manajer untuk melakukan tax avoidance adalah salah satu masalah keagenan. Penghematan pajak dari tax avoidance merupakan sumber pendanaan murah bagi perusahaan dan manfaat tax avoidance secara ekonomi cukup besar, akan tetapi tindakan tax avoidance yang agresif akan menimbulkan risiko dan biaya baik yang terlihat seperti denda atau biaya legal maupun biaya yang tidak terlihat seperti risiko yang besar dan reputasi perusahaan (C. S.Armstrong et.al, 2012 dalam Wahyudi, 2014).

\section{Teori Akuntansi Positif}

Teori Akuntansi positif didasarkan pada proposisi bahwa manajer, pemegang saham, dan regulator (politisi) adalah rasional dan mereka berusaha untuk memaksimalkan utility mereka, yang secara langsung terkait dengan kompensasi dan kemakmuran mereka. Pilihan akuntansi tergantung pada variabelvariabel yang merepresentasi insentif manajemen untuk memilih metode akuntansi dengan kontrak hutang, proses politisi dan rencana bonus. Teori akuntansi positif merupakan teori yang dikembangkan oleh Wats dan Zimmerman (1986:112) yang menjelaskan tentang kebijakan akuntansi dan praktiknya dalam perusahaan serta memprediksi kebijakan apa yang akan dipilih manajer dalam kondisi-kondisi tertentu di masa yang akan datang.

Dalam teori akuntansi positif ada beberapa alternatif akuntansi yang dapat digunakan oleh setiap perusahaan dalam upaya untuk mencapai efisiensi dan efektifitas perusahaan serta tingkat laba yang optimal. Prosedur dan alternatif yang digunakan oleh setiap perusahaan bisa saja berbeda jika dilihat dari berbagai faktor. Perusahaan yang melakukan penghindaran pajak maka laba di laporan keuangan akan ditekankan menjadi lebih rendah, hal ini dapat dilakukan melalui akuntansi yang konservatif.

\section{Tax Avoidance}

Tax avoidance bagi negara merupakan hambatan yang terjadi dalam pemungutan pajak yang mengakibatkan berkurangnya penerimaan kas negara. Tax avoidance selalu diartikan sebagai kegiatan yang legal (Bambang, 2009). Namun penghindaran pajak ini tidak selalu legal karena pada dasarnya tax avoidance dibedakan menjadi dua yaitu penghindaran pajak yang diperbolehkan (acceptable tax avoidance) dan yang tidak diperbolehkan (unacceptable tax avoidance) (Rohatgi dalam Bambang, 2009). Secara hukum, tax avoidance tidak dilarang meskipun seringkali mendapatkan sorotan yang kurang baik dari kantor pajak karena dianggap memiliki konotasi yang negatif. Umumnya rencana pajak merujuk pada proses merekayasa usaha dan transaksi Wajib Pajak (WP) supaya hutang pajak berada dalam jumlah minimal tetapi masih dalam bingkai peraturan. Tax avoidance dapat terjadi dalam undang-undang atau dapat juga terjadi dalam ketentuan undang-undang tetapi berlawanan dengan jiwa undang-undang (Suandy, 2011).

Dalam penelitian Indriani (2016) tax avoidance dapat diukur dengan menggunakan tarif pajak efektif atau lebih dikenal dengan cash effective tax rate (CETR). Cash effective tax rate (CETR) merupakan rasio pembayaran pajak 
secara kas atas laba perusahaan pajak penghasilan. Pembayaran pajak secara kas terdapat pada laporan arus kas tahun berikut pada pos pembayaran pajak penghasilan dalam arus kas untuk aktivitas operasi, sedangkan laba sebelum pajak penghasilan terdapat dalam laporan laba rugi tahun berjalan. Dan pengukuran diharapkan tindakan tax avoidance dapat diidentifikasi, dan dapat diketahui apakah suatu perusahaan melakukan tindakan meminimalkan pajak atau tidak.

\section{Karakteristik Perusahaan terhadap Penghindaran Pajak}

Karakteristik Perusahaan yang digunakan dalam penelitian ini diproksikan melalui leverage. Leverage adalah intensitas penggunaan utang sebagai sumber dana perusahaan. Perusahaan dengan leverage yang tinggi berarti memiliki hutang yang lebih banyak dibanding ekuitasnya. Hal ini dapat membuat perusahaan mengalami kesulitan dalam menanggung beban hutang berupa beban hutang pokok maupun bunga. Kesulitan menanggung beban hutang ini dapat menggiring perusahaan untuk melakukan penghematan beban pajak dengan cara melakukan penghindaran pajak.

Perusahaan yang memiliki likuiditas buruk berarti memiliki hutang jangka pendek yang lebih besar dari aset lancarnya, dan menanggung beban yang lebih berat sehingga dapat mendorong perusahaan melakukan penghindaran pajak sebagai usaha untuk mengurangi beban perusahaan. Dengan demikian, diharapkan leverage tinggi berkaitan dengan ETR yang tinggi. Dalam penelitian yang dilakukan Tati Yulia Okrayanti dkk (2017) menunjukan bahwa leverage tidak berpengaruh terhadap tax avoidance. Sedangkan dalam penelitian Anggy Anugrah Pandini (2017) berpengaruh dan signifikan terhadap tindakan tax avoidance. Berdasarkan uraian di atas maka hipotesis sebagai berikut:

H1 : Karakteristik Perusahaan berpengaruh terhadap Tax Avoidance

\section{Pengaruh Intensitas Aset Tetap terhadap Penghindaran Pajak}

Intensitas Aset Tetap perusahaan menggambarkan banyaknya investasi perusahaan terhadap aset tetap. Intensitas aset tetap merupakan proporsi di mana dalam aset tetap terdapat pos bagi perusahaan untuk menambahkan beban depresiasi yang ditimbulkan oleh aset tetap (Mulyani, 2014). Intensitas aset tetap perusahaan yang besar tentu akan mengakibatkan beban depresiasi atas aset tetap yang besar juga. Dalam manajemen pajak intensitas aset tetap berpotensi menekan beban pajak perusahan, hal tersebut terjadi karena beban depresiasi yang bersifat deductible expense akan berperan sebagai pengurang laba perusahaan yang dijadikan dasar pengenaan pajak. Oleh karenanya, intensitas aset tetap yang tinggi dalam konflik agensi sengaja dimanfaatkan oleh manajer untuk menghindari beban pajak dengan memperbesar investasi dalam aset tetap sehingga dapat memaksimalkan laba perusahaan dan tercapainya kompensasi kinerja manajer yang diinginkan.

Dari penelitian yang dilakukan oleh Darmadi (2013) intensitas aset tetap berpengaruh positif signifikan terhadap tarif pajak efektif perusahaan, seperti yang dijelaskan oleh Blocher (2007) dalam Darmadi (2013) yaitu beban depresiasi memiliki pengaruh pajak dengan bertindak sebagai pengurang pajak. Sedangkan dalam penelitian I Made Surya Darma dan Putu Agus Ardiana (2016) intensitas 
aset tetap berpengaruh negatif terhadap penghindaran pajak. Berdasarkan uraian di atas maka hipotesis sebagai berikut:

H2 : Intensitas Aset Tetap terdapat pengaruh terhadap Tax Avoidance

\section{Pengaruh Konservatisme Akuntansi terhadap Penghindaran Pajak}

Konservatisme Akuntansi menurut Standar Akuntansi Keuangan (SAK) adalah metode akuntansi yang diperbolehkan mengakui pendapatan selambat mungkin, pengakuan beban secepat mungkin, penilaian persediaan yang lebih rendah dan penilaian kewajiban yang lebih tinggi. Pemilihan metode akuntansi yang konservatif untuk menghindari pajak adalah dapat memperkecil besaran pajak terutang perusahaan, karena memilih kebijakan akuntansi yang konservatif akan menciptakan pengakuan beban lebih awal dan tidak langsung mengakui pendapatan (Jaya dkk: 2013).

Dalam penelitian yang dilakukan oleh Verawaty dkk (2015) menyatakan perusahaan dengan pajak semakin besar cenderung memilih kebijakan akuntansi yang konservatif untuk menekan beban pajak terutangnya melalui cara-cara yang diperbolehkan. Dengan semakin minimnya laba maka kewajiban perpajakan yang dibayarkan juga lebih rendah, karena laba perusahaan merupakan dasar pengenaan pajak. Anggy Anugrah Pandini (2017) menyatakan konservatisme akuntansi tidak berpengaruh dan tidak signifikan terhadap penghindaraan pajak dan secara simultan konservatisme akuntansi berpengaruh dan signifikan terhadap tindakan tax avoidance. Berdasarkan uraian di atas, maka dikembangkan hipotesis sebagai berikut:

H3 : Konservatisme Akuntansi berpengaruh terhadap Tax Avoidance

\section{METODOLOGI PENELITIAN}

Penelitian ini dilakukan pada perusahaan pertambangan yang terdaftar di Bursa Efek Indonesia (BEI) melalui situs resminya yaitu www.idx.co.id selama 5 tahun mulai dari tahun 2014-2018. Sampel dipilih melalui metode Purposive Sampling yang menghasilkan 48 perusahaan. Sebelum diolah data diuji Asumsi Klasik yang terdiri dari Uji Normalitas Data, Uji Heteroskedastisitas, Uji Multikolinieritas dan Uji Autokorelasi. Data sampel kemudian diolah menggunakan alat bantu SPSS versi 22 .

\section{Variabel \& Pengukuran}

Variabel independen

1) Karakteristik Perusahaan

Karakteristik Perusahaan merupakan ciri khas yang melekat pada suatu perusahaan, yang dapat dilihat dari berbagai segi antara lain jenis usaha, struktur kepemilikan, likuiditas, profitabilitas, ukuran perusahaan, dan sebagainya. Di sini Karakteristik Perusahaan menggunakan proksi Leverage yang menggambarkan hubungan antara hutang perushaaan terhadap modal maupun aset perusahaan. Rasio leverage menggambarkan sumber dana 
operasi yang digunakan oleh perusahaan. Rasio leverage juga menunjukan risiko yang dihadapi perusahaan (Wirna Yola Gusti, 2013).

$$
\text { Leverage }=\text { DER }=\frac{\text { Jumlah Hutang }}{\text { Modal Sendiri }}
$$

2) Intensitas Aset Tetap

Aset tetap adalah kekayaan perusahaan yang memiliki wujud, mempunyai manfaat ekonomis lebih dari satu tahun dan diperoleh perusahaan untuk melaksanakan kegiatan perusahaan (Mulyadi, 2001:591). Intensitas Aset Tetap adalah gambaran besarnya aset tetap yang dimiliki oleh perusahaan. Intensitas aset tetap dalam peneitian ini dapat dihitung dengan cara total aset tetap yang dimiliki perusahaan dibandingkan dengan total aset perusahaan (Noor et al., 2010 dalam Dharma dan Agus, 2015).

$$
\text { Intensitas Aset Tetap }=\frac{\text { Total Aset Tetap }}{\text { Total Aset }}
$$

3) Konservatisme Akuntansi

Konservatisme Akuntansi mengukur aktiva dan laba dengan kehatihatian oleh karena aktivitas ekonomi dan bisnis yang dilingkupi suatu ketidakpastian yang tercermin dalam laporan keuangan perusahaan untuk memberikan manfaat bagi pengguna laporan keuangan. Implikasinya yaitu pemilihan metode akuntansi pada metode yang mengarahkan pada metode yang melaporkan laba dan aktiva yang lebih rendah atau melaporkan biaya atau utang yang lebih tinggi (Wulandari, 2014) dalam Hery Septianto (2016). Pengukuran konservatisme dilakukan dengan menggunakan ukuran berbasis akrual mengikuti Givoly dan Hayn (2002) yang dihitung dengan cara berikut ini.

\section{CONACCit $=$ NIit - CFOit}

\section{Dimana :}

COACCit $=$ Konservatisme Akuntansi untuk perusahaan i pada peiode $\mathrm{t}$

Niit $=$ Net income ditambah dengan depresiasi dan amortisasi untuk perusahaan i pada periode $\mathrm{t}$

CFOit = Cash flow dari kegiatan operasional untuk perusahaan i pada periode $\mathrm{t}$

Givoly dan Hayn (2002) dan Dwimulyani (2010) dalam Hery Septianto (2016) mengeluarkan akrual depresiasi karena merupakan akrual positif yang akan membalik ketika aset tetap diperoleh dan tidak tertangkap dalam perbedaan antara laba dan aliran kas. Ukuran konservatisme ini dikalikan -1, sehingga semakin besar nilai positif rasio, adalah semakin konservatif. Maka 
demikian rumus mencari total akrual adalah sebagai berikut :

Total Akrual $=\quad$ (Laba bersih - depresiasi $)-$ arus kas operasi $\quad X-1$

1Total Aset

Variabel Dependen

Tax Avoidance yaitu upaya untuk meringankan beban pajak namun tidak melanggar Undang- Undang yang ada (Mardiasmo : 2013). Tax Avoidance merupakan usaha untuk mengurangi atau bahkan meniadakan hutang pajak yang harus dibayar perusahaan dengan tidak melanggar undang-undang yang ada. Menurut Dyreng et. al. (2010) dalam Oktavian (2015) dan Indriani (2016) variabel ini dihitung melalui CETR (Cash effective tax rate) perusahaan yaitu kas yang dikeluarkan untuk biaya pajak dibagi dengan laba sebelum pajak.

\section{$C E T R=\quad \frac{\text { Pembavaran Pajak }}{\text { Laba Sebelum Pajak }}$}

\section{ANALISIS DATA DAN PEMBAHASAN}

Tabel 4.1

Hasil Uji Statikstik Deskripti

\begin{tabular}{|l|r|r|r|r|r|r|}
\hline & \multirow{2}{*}{ N } & Minimum & Maksimum & \multicolumn{2}{|c|}{ Rata- rata } & \multirow{2}{*}{ Std. Deviasi } \\
\cline { 5 - 6 } & & & & Statistic & Std Error & \\
\hline Karakteristik & 65 &, 1694 & 3,5614 &, 7739 &, 0638 &, 5146 \\
$\begin{array}{l}\text { Perusahaan } \\
\text { Intensitas Aset } \\
\text { Tetap }\end{array}$ & 65 &, 1736 &, 9142 &, 5238 &, 0264 &, 2131 \\
$\begin{array}{l}\text { Konservatisme } \\
\text { Akuntansi }\end{array}$ & 65 &, 0137 &, 9810 &, 3463 &, 0290 &, 2339 \\
$\begin{array}{l}\text { Tax Avoidance } \\
\text { Valid N (listwise) }\end{array}$ & 65 &, 1066 & 4,5723 &, 6707 &, 1072 &, 8641 \\
\hline
\end{tabular}

Hasil statistik deskriptif terhadap variabel independen Karakteristik Perusahaan (X1) menunjukkan nilai minimum sebesar 0.1694 adalah Resource Alam Indonesia Tbk (KKGI) pada tahun 2016 dan nilai maximum sebesar 3.5614 adalah Citatah Tbk (CTTH) pada tahun 2014 dengan nilai rata-rata (mean) sebesar 0,7739 . Melihat nilai rata-rata dari proksi DER 0,77 jika dipersenkan menjadi $77 \%$ menunjukkan angka yang cukup tinggi untuk komposisi utang .

Sedangkan hasil statistik deskriptif terhadap variabel independen Intensitas Aset Tetap (X2) menunjukkan nilai minimum sebesar 0,1736 adalah Citatah Tbk (CTTH) pada tahun 2016 dan nilai maximum sebesar 0,9142 adalah J Resources 
Asia Pasific Tbk (PSAB) pada tahun 2015 dengan nilai rata-rata (mean) sebesar 0.5238 dan nilai standar deviasi sebesar 0.2131. Nilai rata-rata 0,5238 menunjukkan angka yang moderat dan seimbang antara aset tetap dengan aset lainnya. Hasil statistik deskriptif terhadap variabel independen Konservatisme Akuntansi (X3) menunjukkan nilai minimum sebesar 0.0137 adalah Toba Bara Sejahtra (TOBA) pada tahun 2014 dan nilai maximum sebesar 0.9810 adalah Samindo Resources Tbk (MYOH) pada tahun 2018 dengan nilai rata-rata (mean) sebesar 0.3463 .

Variabel dependen Tax Avoidance menunjukkan nilai minimum sebesar 0.1066 adalah J Resources Asia Pasific Tbk (PSAB) pada tahun 2014 dan nilai maximum sebesar 4.5723 adalah Citatah Tbk (CTTH) pada tahun 2014 dengan nilai rata-rata (mean) sebesar 0.6707. Melihat nilai rata-ratanya dapat diartikan Tax Avoidance yang terjadi pada pupulasi sampel masih dalam taraf yang rendah.

\section{Uji Hipotesis}

Tabel 4.2
Hasil Uji Hipotesis Parsial

\begin{tabular}{|l|r|r|c|}
\hline Variabel & \multicolumn{1}{|c|}{$\mathrm{t}$} & \multicolumn{1}{|c|}{ Sig. } & Keterangan \\
\hline (Constant) & $-2,389$ &, 020 & \\
\hline Karakteristik Perusahaan & 2,428 &, 018 & H1 : Diterima \\
\hline Intensitas Aset Tetap & $-1,665$ &, 101 & H2 : Ditolak \\
\hline Konservatisme Akuntansi & 1,773 &, 081 & H3 : Ditolak \\
\hline
\end{tabular}

H1 diterima, Karakteristik Perusahaan berpengaruh terhadap Penghindaran Pajak, dengan signifikansi 0.018 dan $\mathrm{t}$ hitung sebesar 2.428 sedangkan t tabel adalah sebesar 1.99962. Hasil penelitian sesuai dengan penelitian yang dilakukan oleh Anggy Anugrah Pandini (2017) yang menyatakan bahwa leverage berpengaruh signifikan terhadap tax avoidance. Penelitian ini juga sesuai dengan yang dilakukan Sri Mulyani (2012) yang menyatakan bahwa leverage secara signifikan mempengaruhi penghindaran pajak. Di mana keputusan perusahaan untuk mendapatkan dana dari pihak ekternal melalui utang, antara lain disebabkan pemikiran untuk dapat memperkecil beban pajak melalui beban bunga yang harus dibayarkan.

$\mathrm{H} 2$, ditolak dengan nilai signifikansi 0.101 dan t hitung $-1.665<1.99962$, artinya Intensitas Aset Tetap tidak berpengaruh terhadap Penghindaran Pajak. Hasil penelitian ini sesuai dengan penelitian yang dilakukan oleh Ida Bagus Putu Fajar Adisamartha dan Naniek Noviari (2015) yang menyatakan bahwa intensitas aset tetap tidak berpengaruh signifikan terhadap penghindaran pajak. Namun penelitian yang dilakukan oleh Putu Agus Ardiana (2016) menyatakan bahwa Intensitas Aset Tetap berpengaruh negative terhadap tax avoidance.

H3 juga ditolak, dengan nilai signifikansi 0.081 dan nilai t hitung sebesar $1.773<1.99962$, sehingga berarti Konservatisme Akuntansi tidak berpengaruh 
terhadap Penghindaran Pajak. Hasil penelitian ini sesuai dengan penelitian Angela Novita Indriani (2019) yang menyatakan bahwa konservatisme akuntansi tidak berpengaruh terhadap tax avoidance. Hal ini sejalan dengan penelitian Bantara Wiro Pramudito dan Maria. Hal ini menunjukan bahwa penggunaan metode akuntansi yang konservatif tidak akan berpengaruh terhadap kecenderungan perusahaan untuk melakukan penghindaran pajak, karena bagi perusahaan pajak merupakan suatu biaya yang harus dibuat seminimal mungkin dan sebisa mungkin harus dihindari apakah dengan menggunakan akuntansi yang konservatif maupun tidak.

\section{KESIMPULAN, KETERBATASAN DAN SARAN}

\section{Kesimpulan}

1) Karakteristik Perusahaan berpengaruh positif terhadap Penghindaran Pajak. Berdasarkan uji parsial t nilai signifikan lebih kecil dari level of significant, yaitu $0.018<0.05$ dengan nilai $t_{\text {hitung }}$ adalah sebesar 2.428 sedangkan $t_{\text {tabel }}$ adalah sebesar 1.99962. Dimana nilai $2.428>1.99962$ sehingga hipotesis $\left(\mathrm{H}_{1}\right)$ diterima.

2) Intensitas Aset Tetap tidak berpengaruh terhadap Penghindaran Pajak. Berdasarkan uji parsial t nilai signifikan lebih besar dari level of significant, yaitu $0.101>0.05$ dengan nilai thitung adalah sebesar -1.665 sedangkan $t_{\text {tabel }}$ adalah sebesar 1.99962. Dimana nilai $-1.665<1.99962$ sehingga hipotesis $\left(\mathrm{H}_{2}\right)$ ditolak.

3) Konservatisme Akuntansi tidak berpengaruh terhadap Penghindaran Pajak. Berdasarkan uji parsial t nilai signifikan lebih besar dari level of significant, yaitu $0.081>0.05$ dengan dan nilai thitung adalah sebesar 1.773 sedangkan

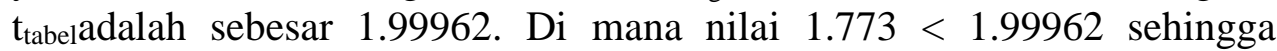
hipotesis $\left(\mathrm{H}_{3}\right)$ ditolak.

\section{Keterbatasan Penelitan}

1) Penelitian ini hanya berfokus pada variabel Karakteristik Perusahaan, Intensitas Aset Tetap dan Konservatisme Akuntansi.

2) Penelitian ini hanya menggunakan sampel Perusahaan Pertambangan yang terdaftar di Bursa Efek Indonesia (BEI) periode tahun 2014-2018. Karena sampel yang digunakan sedikit peneliti mengalami masalah pada saat uji normalitas, sehingga penulis melakukan transform data dan outlier.

\section{Saran}

Untuk peneliti selanjutnya, diharapkan dapat menambahkan variabel lain di luar variabel yang telah dibahas dalam penelitian ini, dan diharapkan menggunakan sampel lain diluar Perusahaan Pertambangan yang telah dibahas dalam 
penelitian ini, hal ini ditujukan agar penelitian yang dilakukan dapat terus berkembang dengan sampel yang lebih luas.

\section{REFERENCES}

Adisamartha, Ida Bagus. (2015). Pengaruh Likuiditas, Leverage, Intensitas Persediaan Dan Intensitas Aset Tetap Pada Tingkat Agresivitas Wajib Pajak. EJurnal Akuntansi Universita Udayana, Vol.13.3.

Baharudin, Ahmad Arif Dan Provita Wijayanti. (2011). Mekanisme Corporate Governance terhadap Konservatisme Akuntansi Di Indonesia. Dinamika Sosial Ekonomi Volume 7 Nomor 1: 86 -101

Darmadi, Iqbal Nul Hakim. (2013). Analisis Faktor Yang Mempengaruhi Manajemen Pajak Dengan Indikator Tarif Pajak Efektif. Simposium Nasional Akuntansi 17 Mataram, Lombok.

Darmawan, Sukartha, (2014). Pengaruh Corporate Governance, Leverage, Return On Asset Dan Ukuran Perusahaan Pada Penghindaran Pajak. Issn : 23028556. E-Jurnal Akuntansi Universitas Udayana.9.1: 143-161.

Dewinta, Ida Ayu Rosa Dan Putu Ery Setiawan (2016). Pengaruh Ukuran Perusahaan, Umur Perusahaan, Profitabilitas, Leverage, Dan Pertumbuhan Penjualan Terhadap Tax Avoidance. E-Jurnal Akuntansi Universitas Udayana, Vol.14.3

Dharma, I M. S., Dan Agus Ardiana. (2015). Pengaruh Leverage, Intensitas Aset Tetap,Ukuran Perusahaan, Dan Koneksi Politik Terhadap Tax Avoidance. EJurnal Akuntansi Universitas Udayana, Vol. 15 No. 3 Hlm. 584-613.

Givoly, Dan dan Hayn, Carla. (2002). "The Changing time-series properties of earnings, cash flows and acruals: Has financial reporting become more conservative". Journal of Accounting Economic 29.

Hery Septianto, (2016). Pengaruh Debt Convenant, Financial Distress, Risiko Lotigasi dan Growth Opportunities Terhadap Konservatisme Akuntansi. Jurnal Akuntansi

Indriani, Angela Novita (2016). Pengaruh Konservatisme Akuntansi Terhadap Tax Avoidance dan Good Corporate Gavernance Sebagai Pemoderasi. E-Jurnal Akuntansi. Stie Perbanas Surabaya.

Irawati, W., \& Sari, A. K. (2019). Pengaruh Persepsi Wajib Pajak dan Preferensi Risiko terhadap Kepatuhan Wajib Pajak. Jurnal Akuntansi Barelang, 3(2), 104-114.

Jaya, Tresno Eka, Kartika Dan Dinda. (2013). Corporate Governance, Konservatisme Akuntansi dan Tax Avoidance. Simposium Nasional Perpajakan 4.

Mardiasmo, (2011). Perpajakan Edisi Revisi 2011. Yogyakarta : Cv. Andi Offset

Mulyani, S. (2014). Pengaruh Karakteristik Perusahaan, Koneksi Politik Dan Reformasi Perpajakan Terhadap Penghindaran Pajak. Jurnal Mahasiswa Perpajakan Universitas Brawijaya, Vol. 1, No. 2 Hlm. 1-9. 
Pohan, Chairil Anwar. (2013). Manajemen Perpajakan Strategi Perencanaan Pajak Dan Bisnis. Jakarta : Gramedia.

Pramudito, B.W., Dan Maria M. Ratna Sari. (2013). Pengaruh Konservatisme Akuntansi, Kepemilikan Manajerial Dan Ukuran Dewan Komisaris Terhadap Tax Avoidance, Jurnal Akuntansi, Vol.13 No.3, Halaman 737742.

Santoso, Singgih. (2014). Statistik Multivariat, Edisi Revisi, Konsep dan Aplikasi dengan SPSS. Penerbit PT. Elex Media Komputindo. Jakarta

Sari, Gusti Maya. (2014). Pengaruh Corporate Governance, Ukuran Perusahaan, Kompensasi Rugi Fiskal dan Struktur Kepemilikan Terhadap Tax Aviodance. Jurnal WRA, Vol.2, No.2. 2014

Sarra, Hustana Dara. (2017). Pengaruh Konservatisme Akuntansi, Komite Audit Dan Dewan Komisaris Independen Terhadap Penghindaran Pajak. E-Jurnal Akuntansi Universitas Muhammadiyah Tangerang

Scott, W. R. (2012). Financial Accounting Theory 6th Edition. Toronto: Pearson Education Canada.

Suandy, Erly (2011). Perencanaan Pajak. Jakarta: Salemba Empat.

Susi, Dwimulyani. (2010). Konservatisma Akuntansi Dan Sengketa Pajak Penghasilan:Suatu Investigasi Empiris. Simposium Nasional Akuntansi XIII Purwokerto.

Tati Yulia Okrayanti Dkk (2017). Pengaruh Karakteristik Perusahaan Dan Corporate Governance Terhadap Tax Avoidance. E-Jurnal Akuntansi Universitas PGRI Madiun

Verawaty, Citra Indah Merina, Fitri Yani. (2015). Insentif Pemerintah (Tax Incentives) Dan Faktor Non Pajak Terhadap Konservatisme Akuntansi Perusahaan Perbankan Di Indonesia. Proceeding Sriwijaya Economic And Business Converence.

Watts, R., Zimmerman, J. (1986). Positive Theory Of Accounting. Jersey: PrenticeHall

www.idx.co.id

www.katadata.co.id 